\title{
Highlight report: the need of 'fit-for-purpose' controls for cell lines used in toxicity assays
}

\author{
Reham Hassan $^{1} \cdot$ Ahmed Ghallab $^{1} \cdot$ Abdel-latif Seddek $^{1}$
}

Received: 7 November 2018 / Accepted: 8 November 2018 / Published online: 14 November 2018

(c) Springer-Verlag GmbH Germany, part of Springer Nature 2018

Recently, Simon Gutbier and colleagues from Konstanz University published an interesting article about the genomic drift of cell lines used for toxicity assays (Gutbier et al. 2018). Cell lines for toxicity testing are difficult to standardize (Nims and Reid 2017; Gore et al. 2011; Laurent et al. 2011). Therefore, journals often ask for authentification of cell line identity. This is usually achieved by short tandem repeat (STR) profiling, using multiplex PCR to simultaneously amplify several STR loci; thereby, for each cell line a unique pattern of repeating DNA is obtained. However, Gutbier and colleagues demonstrated that these standard techniques may not be sufficient. They identified a problem comparing two subpopulations of LUHMES cells maintained at the American Type Culture Collection (ATCC) or by University of Konstanz, the original provider (Gutbier et al. 2018). LUHMES cells are a cell line frequently used in in vitro neurotoxicity testing. They were obtained from an 8-week-old human fetus from precursor cells of the mesencephalon. Interestingly, LUHMES cells banked by ATCC tolerated up to $60 \mu \mathrm{M}$ of the neurotoxic compound $\mathrm{MPP}^{+}$ (1-methyl-4-phenylpyridinium). In contrast, cells maintained in the laboratory of the original provider at Konstanz University showed cytotoxic effects already at $3 \mu \mathrm{M}$ (Gutbier et al. 2018). In the present study, both LUHMES sublines showed normal chromosome structures. Sequencing and genome comparison revealed approximately 70 differences that cause changes of the amino acid sequence. These changes did not lead to a straightforward explanation of

Reham Hassan

hassan@ifado.de

Ahmed Ghallab

Ghallab@vet.svu.edu.eg

Abdel-latif Seddek

abdellatief-shakir@vet.svu.edu.eg

1 Forensic Medicine and Toxicology Department, Faculty of Veterinary Medicine, South Valley University, Qena, Egypt the difference in susceptibility. However, the subline from ATCC downregulated tyrosine hydroxylase and dopamine transporters after differentiation, a problem not seen in the cells maintained in Konstanz (Gutbier et al. 2018).

Currently, numerous laboratories depend on the functionality of cell lines for testing of neurotoxicity (Colaianna et al. 2017; Sisnaiske et al. 2014; Micheli et al. 2018; Meléndez et al. 2018) and developmental neurotoxicity (Shinde et al. 2015, 2016, 2017; Waldmann et al. 2014, 2017; Palloca et al. 2016; Balmer et al. 2014; Weng et al. 2014). Similar problems are faced, when cell lines are used in nephrotoxicity (Cheng et al. 2018; Su et al. 2016; Gong et al. 2016), hepatotoxicity (Hammad et al. 2014; Ghallab 2017; Ghallab et al. 2016; Gu et al. 2018) and cardiotoxicity (Chaudhari et al. 2016a, b) testing. Only when primary cell is isolated the challenge of genetic drifts in vitro is avoided (Godoy et al. 2013; Arbo et al. 2016; Grinberg et al. 2014). The authors of the present study recommend a 'fit-for-purpose test' specifically chosen for the required purpose. In the case of LUHMES cells in neurotoxicity testing, a cytotoxicity test with $\mathrm{MPP}^{+}$seems be adequate to guarantee that cytotoxicity is already observed at concentrations of $3 \mu \mathrm{M}$. The study of Gutbier and colleagues illustrates that conventional methods, e.g. STR profiling, may not be sufficient to guarantee functionality of cell lines in toxicity assays.

\section{Compliance with ethical standards}

Conflict of interest The author declares that he has no conflict of interest.

\section{References}

Arbo MD, Melega S, Stöber R, de Lourdes Bastos M, Carmo H, Hengstler JG (2016) Hepatotoxicity of piperazine designer drugs: upregulation of key enzymes of cholesterol and lipid biosynthesis. Arch Toxicol 90(12):3045-3060 
Balmer NV, Klima S, Rempel E, Rahnenführer J, Waldmann T, Leist M (2014) From transient transcriptome responses to disturbed neurodevelopment: role of histone acetylation and methylation as epigenetic switch between reversible and irreversible drug effects. Arch Toxicol 88(7):1451-1468. https://doi.org/10.1007/ s00204-014-1279-6

Chaudhari U, Nemade H, Gaspar JA, Hescheler J, Hengstler JG, Sachinidis A (2016a) MicroRNAs as early toxicity signatures of doxorubicin in human-induced pluripotent stem cell-derived cardiomyocytes. Arch Toxicol 90(12):3087-3098

Chaudhari U, Nemade H, Wagh V, Keun HC, Hengstler JG, Sachinidis A (2016Bbb) Identification of genomic biomarkers for anthracycline-induced cardiotoxicity in human iPSC-derived cardiomyocytes: an in vitro repeated exposure toxicity approach for safety assessment. Arch Toxicol 90(11):2763-2777

Cheng L, Ge M, Lan Z, Zhang Y, Siegenthaler JA, Chen L (2018) Zoledronate dysregulates fatty acid metabolism in renal tubular epithelial cells to induce nephrotoxicity. Arch Toxicol 92(1):469-485. https://doi.org/10.1007/s00204-017-2048-0

Colaianna M, Ilmjärv S, Peterson H, Hengstler JG, Leist M, Krause KH (2017) Fingerprinting of neurotoxic compounds using a mouse embryonic stem cell dual luminescence reporter assay. Arch Toxicol 91(1):365-391. https://doi.org/10.1007/s00204-016-1690-2

Ghallab A (2017) Highlight report: metabolomics in hepatotoxicity testing. EXCLI J 16:1323-1325. https://doi.org/10.17179/excli 2017-1041 (eCollection 2017. No abstract available)

Ghallab A, Cellière G, Henkel SG, Drasdo D, Gebhardt R, Hengstler JG (2016) Model-guided identification of a therapeutic strategy to reduce hyperammonemia in liver diseases. J Hepatol 64(4):860 871. https://doi.org/10.1016/j.jhep.2015.11.018

Godoy P, Hewitt NJ, Albrecht U, Xu JJ, Yarborough KM, Hengstler JG (2013) Recent advances in 2D and 3D in vitro systems using primary hepatocytes, alternative hepatocyte sources and nonparenchymal liver cells and their use in investigating mechanisms of hepatotoxicity, cell signaling and ADME. Arch Toxicol 87(8):1315-1530

Gong X, Ivanov VN, Hei TK (2016) 2,3,5,6-Tetramethylpyrazine (TMP) down-regulated arsenic-induced heme oxygenase-1 and ARS2 expression by inhibiting Nrf2, NF- $\mathrm{KB}, \mathrm{AP}-1$ and MAPK pathways in human proximal tubular cells. Arch Toxicol 90(9):2187-2200. https://doi.org/10.1007/s00204-015-1600-Z

Gore A, Li Z, Fung HL, Daley GQ, Goldstein LS, Zhang K (2011) Somatic coding mutations in human induced pluripotent stem cells. Nature 2011 Mar 3 471(7336):63-67. https://doi. org/10.1038/nature09805

Grinberg M, Stöber RM, Edlund K, Leist M, Rahnenführer J, Hengstler JG (2014) Toxicogenomics directory of chemically exposed human hepatocytes. Arch Toxicol 88(12):2261-2287

Gu X, Albrecht W, Edlund K, Han B, Hengstler JG, Stoeber R (2018) Relevance of the incubation period in cytotoxicity testing with primary human hepatocytes. Arch Toxicol. https://doi.org/10.1007/ s00204-018-2302-0

Gutbier S, May P, Berthelot S, Gstraunthaler G, Waldmann T, Leist M (2018) Major changes of cell function and toxicant sensitivity in cultured cells undergoing mild, quasi-natural genetic drift. Arch Toxicol. https://doi.org/10.1007/s00204-018-2326-5 (Epub ahead of print)

Hammad S, Hoehme S, Friebel A, Gebhardt R, Drasdo D, Hengstler JG (2014) Protocols for staining of bile canalicular and sinusoidal networks of human, mouse and pig livers, three-dimensional reconstruction and quantification of tissue microarchitecture by image processing and analysis. Arch Toxicol 88(5):1161-1183

Laurent LC ${ }^{1}$, Ulitsky I, Slavin I, Nievergelt CM, Shamir R, Loring JF (2011) Dynamic changes in the copy number of pluripotency and cell proliferation genes in human ESCs and iPSCs during reprogramming and time in culture. Cell Stem Cell 8(1):106-118. https ://doi.org/10.1016/j.stem.2010.12.003

Meléndez C, Muñoz P, Segura-Aguilar J (2018) DT-diaphorase prevents aminochrome-induced lysosome dysfunction in SH-SY5Y Cells. Neurotox Res. https://doi.org/10.1007/s12640-018-9953-8 (Epub ahead of print)

Micheli L, Mattoli L, Maidecchi A, Pacini A, Ghelardini C, Di Cesare Mannelli L (2018) Effect of Vitis vinifera hydroalcoholic extract against oxaliplatin neurotoxicity: in vitro and in vivo evidence. Sci Rep 8(1):14364. https://doi.org/10.1038/s41598-018-32691-w

Nims RW, Reid Y (2017) Best practices for authenticating cell lines. In Vitro Cell Dev Biol Anim 53:880-887. https://doi.org/10.1007/ s11626-017-0212-8

Pallocca G, Grinberg M, Henry M, Sachinidis A, Rahnenführer J, Leist M (2016) Identification of transcriptome signatures and biomarkers specific for potential developmental toxicants inhibiting human neural crest cell migration. Arch Toxicol 90(1):159-180. https:// doi.org/10.1007/s00204-015-1658-7

Shinde V, Stöber R, Nemade H, Sotiriadou I, Hescheler J, Hengstler J, Sachinidis A (2015) Transcriptomics of hepatocytes treated with toxicants for investigating molecular mechanisms underlying hepatotoxicity. Methods Mol Biol 1250:225-240. https://doi. org/10.1007/978-1-4939-2074-7_16

Shinde V, Perumal Srinivasan S, Henry M, Leist M, Hengstler JG, Sachinidis A (2016) Comparison of a teratogenic transcriptomebased predictive test based on human embryonic versus inducible pluripotent stem cells. Stem Cell Res Ther 7(1):190

Shinde V, Hoelting L, Srinivasan SP, Hengstler JG, Leist M, Sachinidis A (2017) Definition of transcriptome-based indices for quantitative characterization of chemically disturbed stem cell development: introduction of the STOP-Tox ${ }_{\mathrm{ukn}}$ and STOP-Tox ${ }_{\mathrm{ukk}}$ tests. Arch Toxicol 91(2):839-864

Sisnaiske J, Hausherr V, Krug AK, Zimmer B, Hengstler JG, Leist M, van Thriel C (2014) Acrylamide alters neurotransmitter induced calcium responses in murine ESC-derived and primary neurons. Neurotoxicology 43:117-126. https://doi.org/10.1016/j.neuro .2014.03.010

Su R, Xiong S, Zink D, Loo LH (2016) High-throughput imagingbased nephrotoxicity prediction for xenobiotics with diverse chemical structures. Arch Toxicol 90(11):2793-2808

Waldmann T, Rempel E, Balmer NV, Rahnenführer J, Hengstler JG, Leist M (2014) Design principles of concentration-dependent transcriptome deviations in drug-exposed differentiating stem cells. Chem Res Toxicol 27(3):408-420. https://doi.org/10.1021/ tx $400402 \mathrm{j}$

Waldmann T, Grinberg M, König A, Rahnenführer J, Hengstler JG, Leist M (2017) Stem cell transcriptome responses and corresponding biomarkers that indicate the transition from adaptive responses to cytotoxicity. Chem Res Toxicol 30(4):905-922

Weng MK, Natarajan K, Scholz D, Ivanova VN, Sachinidis A, Hengstler JG, Waldmann T, Leist M (2014) Lineage-specific regulation of epigenetic modifier genes in human liver and brain. PLoS One 9(7):e102035. https://doi.org/10.1371/journal.pone.0102035 (eCollection 2014) 